\title{
Setting up architecture for environmental tax system under certain socioeconomic conditions
}

\section{Tetyana Vasylieva}

Department of Finance and Entrepreneurship,

Sumy State University, Ukraine

tavasilyeva@fem.sumdu.edu.ua

ORCID 0000-0003-0635-7978

\section{Veronika Machová}

School of Expertness and Valuation,

The Institute of Technology and Business in Ceské Budèjovice,

Czech Republic

machova@mail.vstecb.cr

ORCID 0000-0001-5479-6655

\author{
Alina Vysochyna \\ Department of Accounting and Taxation, \\ Sumy State University, Ukraine \\ a.vysochyna@uabs.sumdu.edu.ua \\ ORCID 0000-0001-9490-1026
}

\section{Joanna Podgórska}

University of Information Technology and Management in Rzeszow,

Rzeszow, Poland

jpodgorska@wsiz.edu.pl

ORCID 0000-0002-6625-2767

\section{Yaryna Samusevych}

Department of Accounting and Taxation,

Sumy State University, Ukraine

y.samuserych@uabs.sumdu.edu.ua

ORCID 0000-0001-7048-8388

Abstract. In this paper, four groups of countries were studied using Ward's hierarchical clustering method and considering the most informative and relevant indicators of socioeconomic development, which include countries with convergent socioeconomic trends. For each of the identified clusters, based on the panel data regression analysis, we have determined the relationships between

Received: January, 2020 1st Revision: September, 2020 Accepted: December, 2020 
changes in tax revenues from energy, transport, pollution environmental taxes and GDP growth rate. Based on the generalization of the results of cluster and regression analyses, the structural and functional patterns of architecture for the environmental tax system were formalized, taking into account the specifics of $8330.2020 / 13-4 / 19$ countries' socioeconomic development.

Keywords: energy environmental taxes, transport environmental taxes, environmental taxes on pollution / resources, architecture of environmental tax system, socioeconomic development.

JEL Classification: C43, E62, F52, H23

\section{INTRODUCTION}

Environmental issues play a crucial role in countries' social, economic, and institutional sustainable development as proved by numerous theoretical and empirical research results (Grybaite \& Stankevičiené, 2018; Rui et al., 2019, and others), and also supported by Sustainable Development Goals (8 of 17 Sustainable Development Goals are more or less built on environmental perspectives). Moreover, the efficiency of national and supranational environmental policy together with different kinds of environmental risks and challenges are also considered as preconditions of regional and municipal socioeconomic development (Lyulyov et al., 2015; Matvieieva, Myroshnychenko \& Valenkevych, 2019; Petrushenko et al., 2020; Raszkowski \& Bartniczak, 2018). While another group of scientists focused their attention on the identification of financial and non-financial benefits from the implementation of environmental responsibility at the corporate level (Alimuddin et al., 2020; Atkociuniene \& Mikalauskiene, 2019; He, 2019; Holotová, Nagyová, \& Holota, 2020; Kasych \& Vochozka, 2017; Mačaitytė \& Virbašiūtė, 2018; Makarenko et al., 2019; Myroshnychenko et al., 2019; Vafaei et al., 2019).

Moreover, scientists also argued that not only country, regional, and corporate socioeconomic development and sustainability highly dependent on environmental issues, but also environmental tax system architecture is affected by different socioeconomic determinants. Specifically, Sokolovska et al. (2020) provided empirical evidence that globalization processes and international tax competition determine tax policy framework and changes in critical elements of taxes. Namely, the authors revealed that higher involvement in a globalized market environment is associated with an increase of general tax burden, while this tax burden is shifting from labour and capital to consumption tax bases.

Thus, considerable empirical evidence confirms the positive influence of environmental issues at national, regional (municipal), and corporate levels. Simultaneously, there is a lack of research aimed at the specification of tax system architecture (especially, environmental tax system) under certain socioeconomic conditions, which leads to the necessity of further scientific and empirical searches in this direction.

\section{LITERATURE REVIEW}

While scientists focus their attention on clarification of the impact of environmental issues on economic and social perspectives of development at different levels, it is also essential to clarify vice-versa cohesion: whether there are socioeconomic preconditions of environmental policy framework in general terms and specificity of fiscal instruments usage depending on social, economic or institutional determinants. Thus, considering that the research is aimed at the identification of the architecture of environmental tax system under socioeconomic conditions, the block of the literature review will be focused on clarification of general socioeconomic determinants influencing country environmental policy and 
peculiarities of fiscal instruments implementation in terms of fulfillment of environmental targets at national, regional (municipal) and corporate levels.

In terms of clarification of socioeconomic determinants of country environmental policy, it should be noted that there is a considerable block of empirical studies, which are clarifying the importance of innovations in the fulfillment of environmental targets. Specifically, Bilan et al. (2020) using GLS regression analysis for the sample of $28 \mathrm{EU}$ member states in 2010-2016 empirically proved that implementation of eco-innovations has a statistically significant influence on business performance indicators (intensification of the process of eco-innovation implementation is associated with a decrease in the number of enterprises due to enhancing requirements for their competitiveness, but positively affected company capitalization) and important country macroeconomic parameters (an increase of eco-innovations has a positive impact on employment level and country's investment attractiveness, but negatively influence the share of value-added created by the real sector of the national economy). Mikhaylova et al. (2019) also pointed out that the expansion of innovations positively affected country and regional economic and environmental performance (based on Baltic countries' experience). While Stankevičienè and Nikanorova (2020), based on the analysis of the Baltic Sea Region countries' experience, also provide empirical evidence that ecoinnovations are an integral pillar of sustainable development. Thus, we can summarize that boosting national, municipal, and entrepreneurial innovative growth will positively impact environmental transformations.

It should also be noted that expansion of investments and increase of financial capacity become core preconditions of environmental projects and initiatives implementation at corporate and national levels because business entities (especially in developing countries) have an opportunity to invest in environmentally-friendly technologies after covering basic company needs. Consequently, creating a favorable investment climate on the national level allows for extra investments in national economic development, including environmental modernization. Specifically, Pavlyk (2020) empirically proved that the green investment increase leads to improvement of energy efficiency by 0,56 points, gross domestic product per capita - 0,18 points, renewable energy - 0,39 points (considering the experience of EU countries and Ukraine in 2009-2019). In turn, Chygryn et al. (2018) and Pimonenko et al. (2020) researched green bond usage perspectives to ensure environmental targets fulfillment and obtain some financial benefits. Authors specified the advantages and disadvantages of green bonds considering Ukrainian and European experience and highlighted economic, social, political, and environmental benefits of its usage, and clarified the most attractive green market spheres for investors. Hrytsenko (2014) also pointed out that the development of national and regional environmental infrastructure and company ecological modernization might become one of the preferable direction of public-private partnership in prioritizing investment support of the national economy of Ukraine. Therefore, we might conclude that the expansion of both national and foreign investment activity creates a precondition for environmental modernization and environmental infrastructure development, which, in turn, might help to mitigate country energy security risks.

Moreover, scientists also argued that environmental policy's main vectors are closely dependent on the country's energy security and priorities. Specifically, Atta Mills, Zeng, and Baafi (2020), based on the analysis of data on carbon emissions, economic growth and energy consumption in the USA and China in 19802017 using the Granger causality test, found out that in these two countries there is an inverse dependency between the scale of energy use and country economic development, while there is no statistically significant evidence of greenhouse gas emission on the economic welfare of both countries. Thus, we can underline that the priority vector of environmental policy for some developed economies is not highly connected to the air pollution, but to the environmental modernization of energy sector, responsible energy consumption, and expansion of renewable electricity production. Besides, Bilan et al. (2018) identified relevant factors that 
affected country food security in 28 post socialistic countries in 2000-2016 and gained familiar empirical findings: electricity consumption and growth of unproductive energy losses negatively affect food security. In turn, the authors also confirmed that many other environmental determinants (coal and fossil fuels use for electricity) positively impact the level of country security. At the same time, Vysochyna et al. (2020) realized familiar empirical research to identify country food security's environmental determinants in shortrun and long-run perspectives. Thus, it was revealed that reducing carbon dioxide emissions, electrification of rural populations, access to clean fuels, renewable energy production, arable land, and forest area growth allowed ensuring countries' food security in the long-run. In turn, Sibanda and Ndlela (2020), while analyzing the link between carbon emissions, agricultural output, and industrial output considering South Africa experience in 1970-2017, also revealed that carbon emission had no statistically significant negative impact on agricultural production and industrial production. Still, there was an inverse dependency (expansion of greenhouse gases negatively affected agricultural output and country food security). Therefore, this group of scientists papers leads us to the conclusion that for less developed countries to ensure their economic security and sustainable development by far wider range of environmental factors matter compared with highly developed countries. In turn, Stavytskyy et al. (2018) pointed out that country energy security might consider proxies of energy production, distribution and consumption, and productivity and efficiency of electricity resources usage. The authors also revealed that a decrease in energy security results in slowing GDP growth and boosting inflation. Piłatowska and Włodarczyk (2018) also found empirical evidence that there are strong relationships between economic growth and energy consumption in highly developed European countries (Netherlands, Belgium, Germany, the UK, Spain, Greece, Italy, and Portugal), while greenhouse gas emission becomes relevant for less developed European countries in terms of ensuring sustainable economic development.

Meanwhile, Chovancová and Tej (2020) found empirical evidence of decoupling the economic growth of the energy sector and greenhouse emissions produced by the energy sector in 1995-2016 in V4 countries. While Bhowmik (2019) proved that there was is an inverse U-shape relationship between CO2 emission per capita and GDP per capita in the Nordic countries during 1970-2016. Therefore, it proves the hypothesis that in current conditions, the country's environmental policy might be focused mostly on strengthening energy security and less on limitation of greenhouse gas emission.

It should also be noted that there is a block of research, which is specifically aimed at the analysis of environmentally-friendly energy-sourced expansion (renewable energy). Specifically, Cebula et al. (2018) focused on assessing biogas potential as an alternative energy source in Ukraine and Israel and found out the development of this renewable energy segment has positive significant environmental and economic consequences for both countries. Vasylyeva and Pryymenko (2014), Kharlamova, Nate and Chernyak (2016), Mentel et al. (2018), Jonek-Kowalska (2019) also argued that country energy security depends on numerous economic and environmental preconditions, while the development of the renewable energy sector and environmental modernization of traditional energy stations might become essential steps on the way on ensuring country energy security and decreasing electricity prices. Specifically, the authors highlighted that an increase in country energy security damages might increase alternative energy sources' popularity and, consequently, prioritize environmental issues.

Moreover, institutional restrictions and limitations might negatively affect the efficiency of country environmental policy, while adopting international environmental recommendations into national legislation might boost positive environmental transformations (Koziuk et al., 2019; Kubaienko, 2018; Ślusarczyk, 2018; Vasilyeva et al., 2020). Thus, Koziuk et al. (2019) confirm the hypothesis that the quality of institutions (alongside the stringency of environmental regulatory requierements) has a positive impact on national economies' competitiveness. In turn, Kubaienko (2018) specified that the synchronization of national legislation to European standards is now one of Ukraine's legislative and institutional framework 
development's critical targets. The author also mentioned that such a transformation might improve Ukraine's environmental sustainability, energy security, and general socioeconomic development. Specifically, Ślusarczyk (2018) argued that country attractiveness for foreign investors highly dependent on the sufficiency of business environment regulation and general macroeconomic stability, while the expansion of foreign direct investment allows improving corporate ecological performance and consequently helps fulfillment of national environmental targets. While, Vasilyeva et al. (2020), Bilan et al. (2019) realized comprehensive research on how institutional quality parameters influence a country's socioeconomic development. Namely, under the regression analysis of the relevant data for 20 countries, there is a strong correlation (0.78) between GDP growth rate and institutional quality. It was also proved that the improvement of institutional quality helps to decrease the GDP gap. Besides, Dkhili (2018), under the analysis with the Generalized Method of Moments on data sample for 187 countries during 20022015, found out that good institutional quality improves environment performance in developed countries. Thus, we can summarize that institutional factors play a crucial role in ensuring the country's socioeconomic development and environmental sustainability.

Summarising this research block, we can underline that the environmental policy framework depends on numerous factors (expansion of innovations, investment attractiveness, economic growth dynamics, energy security, institutional quality, etc.). At the same time, there is a lack of research on how the environmental tax system's architecture depends on it. Specifically, there are only a few papers on this concern. Namely, Vysochyna, Samusevych, and Tykhenko (2015), Boiko and Samusevych (2017), Ngoc Huy (2018), and Eddassi (2020) pointed out priorities of national tax policy are formed under challenges of international tax competitions. Still, there is no specific evidence about the influence of socioeconomic trends on the variety of fiscal measures of environmental policy realization.

\section{METHODOLOGY}

The research aims to recommend the environmental tax system's architecture, considering its social and economic conditions. In order to fulfill the research objectives, it is developed an approach that consists of several stages such as follows: 1) formation of the informational background of the research; 2) correlation analysis aimed at eliminating those control variables that cause to multicollinearity problem; 3) cluster analysis aimed at clarifying group of countries that have common trends $\mathrm{f}$ social and economic development; 4) panel data regression analysis aimed at the identification of the most favorable group of environmental taxes for the country cluster.

In terms of the detailed characteristics of the first stage of the research, it should be noted that the sample of independent variables consists of three indicators characterizing the environmental tax system such as the ratio of energy taxes to total revenues from taxes and social contributions (including imputed social contributions), \% (Energy); the ratio of transport taxes to total revenues from taxes and social contributions (including imputed social contributions), $\%$ (Transport); the ratio of taxes on pollution/resources to total revenues from taxes and social contributions (including imputed social contributions), \% (Pollution). All the data were collected from the Environmental tax statistics that are provided by Eurostat. In turn, the GDP growth rate is an independent variable. In order to increase reliability of the panel data regression research results it was also collected a block of control variables, namely: Consumer price index $(2010=100)(C P I)$; Trade openness (Trade); GDP per capita (constant 2010 US Dollars) (GDPpc); Gross fixed capital formation (\% of GDP) (GFCF); Income share held by lowest $20 \%$ (Pov); Industry (including construction), value added (\% of GDP) (IVA); Research and development expenditure (\% of GDP) (RD); Unemployment, total (\% of total labor force) (national estimate) (Unemp); 
Current account balance (\% of GDP) (CAB). In brackets in italic, it is mentioned variable marker. All the data were collected from the World Bank World Development Indicators database.

The country sample consists of 30 European countries: Belgium (1), Bulgaria (2), Czech Republic (3), Denmark (4), Germany (5), Estonia (6), Ireland (7), Greece (8), Spain (9), France (10), Croatia (11), Italy (12), Cyprus (13), Latvia (14), Lithuania (15), Hungary (16), Malta (17), the Netherlands (18), Austria (19), Poland (20), Portugal (21), Romania (22), Slovenia (23), Slovak Republic (24), Finland (25), Sweden (26), United Kingdom (27), Iceland (28), Norway (29), and Switzerland (30). In brackets, it is mentioned country ID number. Period of observations - 2009-2018 (or period of the latest available data).

Summative statistics for the whole data sample is in Table 1.

Table 1

Summative statistics

\begin{tabular}{|l|c|c|c|c|c|}
\hline Variable & Observation & Mean & $\begin{array}{c}\text { Standard } \\
\text { deviation }\end{array}$ & Min & Max \\
\hline Energy & 300 & 5.453 & 1.667 & 2 & 9.82 \\
\hline Transport & 300 & 1.507 & 0.953 & 0.04 & 4.55 \\
\hline Pollution & 300 & 0.256 & 0.282 & 0 & 1.36 \\
\hline CPI & 300 & 105.938 & 5.276 & 94.258 & 125.229 \\
\hline Trade & 300 & 3.28 & 5.719 & -9.779 & 33.141 \\
\hline GDPg & 300 & 1.377 & 3.693 & -14.814 & 25.163 \\
\hline GDPpc & 300 & 34540.51 & 20286.46 & 6709.527 & 92119.52 \\
\hline GFCF & 300 & 20.776 & 3.378 & 11.074 & 35.632 \\
\hline Pov & 262 & 7.77 & 1.23 & 4.9 & 10.2 \\
\hline IVA & 298 & 23.398 & 5.728 & 9.887 & 38.516 \\
\hline RD & 261 & 1.613 & 0.883 & 0.382 & 3.749 \\
\hline Unemp & 300 & 9.029 & 4.751 & 2.243 & 27.466 \\
\hline CAB & 300 & 1.3 & 4.746 & -10.893 & 14.701 \\
\hline
\end{tabular}

Thus, based on the information presented in Table 1, it should be mentioned that there are some omitted observations. Still, the panel is strongly balanced, and these omitted values do not influence the adequacy of the research results. Besides, we can underline that in the above mentioned 30 countries, energy taxes ensure the most significant contributions to total tax revenue: it ratio varies from $2 \%$ to $9.82 \%$; the second position in terms of the ratio to total revenues from taxes and social contributions have transport environmental taxes: from $0.04 \%$ to $4.55 \%$. Group of environmental taxes on pollution/resources ensure the least significant contributions to total tax revenue - less than $1.36 \%$.

In terms of the characteristic of the second stage of the research, it should be noted that it would be constructed a correlation matrix in Stata software. All control variables with a correlation coefficient of more than 0.5 might be eliminated to solve the multicollinearity problem.

At the third stage of the research, it would be realized cluster analysis based on Ward's clustering method in Stata software to identify groups of countries with common socioeconomic development trends. Cluster analysis will be based on all control variables that will pass the multicollinearity correlation test.

The final stage of the research aimed to clarify the cohesion between GDP growth rate and environmental taxes ratio to total revenues from taxes and social contributions to identify those fiscal instruments of environmental policy, which boost economic development and ensure country economic security. It will be realized under the panel data regression analysis in Stata software separately for each country cluster clarified at the previous research stage. 
Research results identify the most vital fiscal environmental instruments to boost the country's economic growth and ensure economic security and create specific recommendations on the environmental tax system's architecture under certain socioeconomic conditions.

\section{EMPIRICAL RESULTS AND DISCUSSION}

After forming the research's informational background, the next stage aimed at testing control variables, which are proxies of country socioeconomic development, on multicollinearity using correlation analysis. This step might help eliminating correlated control variables to avoid their insufficient impact on regression results. The correlation matrix is presented in Table 2.

Table 2

Correlation matrix of control variables

\begin{tabular}{|c|c|c|c|c|c|c|c|c|c|c|}
\hline Variables & (1) & (2) & (3) & (4) & (5) & (6) & (7) & (8) & (9) & $(10)$ \\
\hline (1) CPI & 1.000 & & & & & & & & & \\
\hline (2) Trade & 0.142 & 1.000 & & & & & & & & \\
\hline (3) GDPg & 0.445 & 0.347 & 1.000 & & & & & & & \\
\hline (4) GDPpc & -0.064 & 0.461 & 0.056 & 1.000 & & & & & & \\
\hline (5) GFCF & 0.047 & 0.051 & 0.133 & 0.096 & 1.000 & & & & & \\
\hline (6) Pov & -0.059 & 0.436 & 0.097 & 0.511 & 0.209 & 1.000 & & & & \\
\hline (7) IVA & 0.055 & 0.221 & 0.141 & 0.006 & 0.442 & 0.116 & 1.000 & & & \\
\hline (8) RD & -0.006 & 0.276 & -0.006 & 0.663 & 0.187 & 0.559 & 0.049 & 1.000 & & \\
\hline (9) Unemp & -0.169 & -0.264 & -0.226 & -0.369 & -0.459 & -0.537 & -0.303 & -0.368 & 1.000 & \\
\hline (10) $\mathrm{CAB}$ & 0.198 & 0.747 & 0.219 & 0.558 & 0.060 & 0.350 & 0.167 & 0.408 & -0.290 & 1.000 \\
\hline
\end{tabular}

Thus, all cells that are shadowed illustrate the high or moderate correlation between control variables according to the Chaddock scale. Considering correlation coefficients, such variables as current account balance ( $\%$ of GDP) (CAB), income share held by lowest 20\% (Pov), and research and development expenditure (\% of GDP) (RD) might be eliminated before regression analysis.

The next stage of the research aims to clarify a group of countries with common socioeconomic development trends based on the cluster analysis. Cluster dendrogram is presented in Figure 1.

Considering cluster analysis results, we can identify 4 clusters of countries such as follows:

- cluster 1: Belgium (1), Denmark (4), Germany (5), France (10), the Netherlands (18), Austria (19), Finland (25), Sweden (26), United Kingdom (27), Iceland (28);

- cluster 2: Ireland (7), Norway (29), and Switzerland (30);

- cluster 3: Bulgaria (2), Estonia (6), Croatia (11), Latvia (14), Lithuania (15), Hungary (16), Poland (20), Romania (22), Slovak Republic (24);

- cluster 4: Czech Republic (3), Greece (8), Spain (9), Italy (12), Cyprus (13), Malta (17), Portugal (21), Slovenia (23).

The next stage of the research aimed to test the hypothesis about influence of energy, transport, pollution / resource environmental tax on GDP growth rate (primary hypothesis is about existing positive cohesion between dependent and independent variables). Panel data regression results for the countries from cluster 1 are presented in Table 3 .

Table 3 presents the quantitative evaluation results of our scientific hypotheses that were made to understand how different types of environmental taxes influence economic dynamics in the group of the most developed countries in economic and social perspectives. Thus, we can conclude that an increase of the ratio of transport tax to total revenues from taxes and social contributions (including imputed social 
contributions) in $1 \%$ results in the decrease of GDP growth rate in $1.081 \%$ at a $5 \%$ confidence interval. Another group of environmental taxes has no significant influence on highly developed European countries' economic growth rate. Therefore, we can underline that environmental taxes are no instrument of country economic development in this group of countries. Moreover, it should be mentioned that these regression results might not be considered as highly reliable because the overall coefficient of determination is relatively insignificant. All independent variables included in the model allow explaining only $33.8 \%$ of the dependent variable variation.

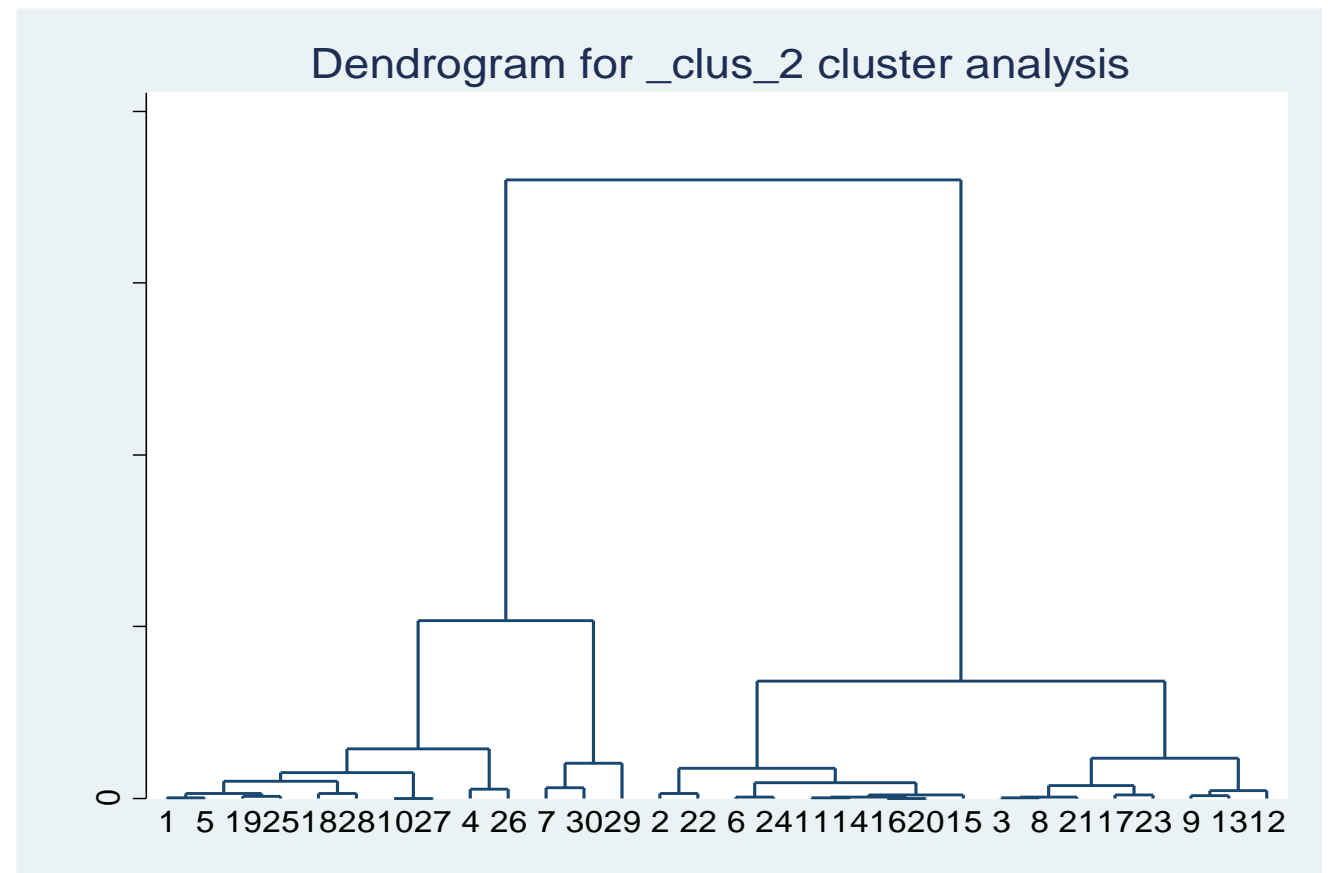

Figure 1. Cluster analysis results

Table 3

Regression results for cluster 1

\begin{tabular}{|c|c|c|c|c|c|c|c|}
\hline & \multirow{2}{*}{$\begin{array}{c}\text { Coefficient } \\
0.085\end{array}$} & \multirow{2}{*}{$\begin{array}{c}\text { Standard } \\
\text { Error }\end{array}$} & \multirow{2}{*}{$\begin{array}{c}\text { t-value } \\
0.17 \\
\end{array}$} & \multirow{2}{*}{$\frac{\mathrm{p} \text {-value }}{0.862}$} & \multicolumn{2}{|c|}{$95 \%$ Confidence Interval } & \multirow[t]{2}{*}{ Sig } \\
\hline Energy & & & & & -0.866 & 1.035 & \\
\hline Transport & -1.081 & 0.511 & -2.12 & 0.034 & -2.083 & -0.080 & $* *$ \\
\hline Pollution & 2.200 & 1.869 & 1.18 & 0.239 & -1.464 & 5.863 & \\
\hline CPI & 0.243 & 0.051 & 4.74 & 0.000 & 0.143 & 0.344 & $* * *$ \\
\hline Trade & -0.262 & 0.181 & -1.45 & 0.147 & -0.617 & 0.092 & \\
\hline GDPpc & 0.000 & 0.000 & 2.40 & 0.016 & 0.000 & 0.000 & $* *$ \\
\hline GFCF & -0.094 & 0.157 & -0.60 & 0.549 & -0.403 & 0.214 & \\
\hline IVA & 0.214 & 0.176 & 1.22 & 0.223 & -0.130 & 0.558 & \\
\hline Unemp & 0.033 & 0.189 & 0.17 & 0.862 & -0.337 & 0.402 & \\
\hline Constant & -36.408 & 8.520 & -4.27 & 0.000 & -53.108 & -19.709 & $* * *$ \\
\hline \multicolumn{2}{|l|}{ Mean dependent var } & 1.145 & \multirow{2}{*}{\multicolumn{2}{|c|}{$\begin{array}{l}\text { SD dependent var } \\
\text { Number of obs }\end{array}$}} & \multicolumn{2}{|r|}{2.470} & \\
\hline \multicolumn{2}{|l|}{ Overall r-squared } & 0.338 & & & \multicolumn{2}{|r|}{98.000} & \\
\hline \multicolumn{2}{|l|}{ Chi-square } & 44.880 & \multicolumn{2}{|c|}{ Prob $>$ chi 2} & \multicolumn{2}{|r|}{0.000} & \\
\hline \multicolumn{2}{|l|}{ R-squared within } & 0.364 & \multicolumn{2}{|c|}{ R-squared between } & & \\
\hline
\end{tabular}

Source: Authors' calculations. Sig - significance level: * indicates significance at 0.10 level, $* *$ indicates significance at 0.05 level, $* * *$ indicates significance at 0.01 level 
Regression analysis results for the second cluster that consists of Ireland, Norway, and Switzerland are presented in Table 4.

Table 4

Regression results for cluster 2

\begin{tabular}{|c|c|c|c|c|c|c|c|}
\hline & \multirow{2}{*}{$\frac{\text { Coefficient }}{3.629}$} & \multirow{2}{*}{$\begin{array}{c}\begin{array}{c}\text { Standard } \\
\text { Error }\end{array} \\
3.730\end{array}$} & \multirow{2}{*}{$\frac{\text { t-value }}{0.97}$} & \multirow{2}{*}{$\frac{\mathrm{p} \text {-value }}{0.331}$} & \multicolumn{2}{|c|}{$95 \%$ Confidence Interval } & \multirow[t]{2}{*}{ Sig } \\
\hline Energy & & & & & -3.682 & 10.940 & \\
\hline Transport & 16.571 & 5.569 & 2.98 & 0.003 & 5.656 & 27.486 & *** \\
\hline Pollution & -101.021 & 27.330 & -3.70 & 0.000 & -154.587 & -47.454 & $* * *$ \\
\hline CPI & 0.442 & 0.210 & 2.11 & 0.035 & 0.031 & 0.853 & $* *$ \\
\hline Trade & 0.053 & 0.297 & 0.18 & 0.858 & -0.530 & 0.636 & \\
\hline GDPpc & 0.001 & 0.000 & 3.63 & 0.000 & 0.001 & 0.002 & $* * *$ \\
\hline GFCF & -0.387 & 0.351 & -1.10 & 0.271 & -1.075 & 0.302 & \\
\hline IVA & 0.435 & 0.420 & 1.04 & 0.300 & -0.388 & 1.257 & \\
\hline Unemp & 2.556 & 1.127 & 2.27 & 0.023 & 0.346 & 4.765 & $* *$ \\
\hline Constant & -197.243 & 41.019 & -4.81 & 0.000 & -277.639 & -116.847 & *** \\
\hline \multicolumn{2}{|l|}{ Mean dependent var } & 2.669 & \multirow{2}{*}{\multicolumn{2}{|c|}{ SD dependent var }} & \multicolumn{2}{|r|}{5.058} & \\
\hline \multicolumn{2}{|l|}{ Overall r-squared } & 0.761 & & & \multicolumn{2}{|r|}{30.000} & \\
\hline \multicolumn{2}{|l|}{ Chi-square } & 63.621 & \multicolumn{2}{|c|}{ Prob > chi 2} & \multicolumn{2}{|r|}{0.000} & \\
\hline \multicolumn{2}{|l|}{ R-squared within } & 0.725 & \multicolumn{2}{|c|}{ R-squared between } & \multicolumn{2}{|r|}{0.997} & \\
\hline
\end{tabular}

Source: Authors' calculations. Sig - significance level: * indicates significance at 0.10 level, ** indicates significance at 0.05 level, *** indicates significance at 0.01 level

Thus, based on the panel data regression analysis, we can conclude that the second cluster model is by far more reliable: all dependent variables explain $76.1 \%$ of GDP growth rate variation. Moreover, it is also empirically proved that transport taxes positively influence economic dynamics in these counties: an increase of the independent variable in $1 \%$ results in a rise in GDP growth rate of $16.57 \%$ at $1 \%$ level. In turn, the increase of taxes on pollution/resources negatively affected the country's economic growth. Thus, we can conclude that to boost the country's economic development in Ireland, Norway, and Switzerland, the core element of environmental taxes should be transport taxes. In contrast, taxes on pollution/resources might be a less priority economic and environmental policy instrument.

Regression results for the third cluster that consists of former socialistic developed European countries are in Table 5.

Table 5

Regression results for cluster 3

\begin{tabular}{|c|c|c|c|c|c|c|c|}
\hline & \multirow{2}{*}{$\begin{array}{c}\text { Coefficient } \\
0.928\end{array}$} & \multirow{2}{*}{$\begin{array}{c}\text { Standard } \\
\text { Error } \\
0.333\end{array}$} & \multirow{2}{*}{$\frac{\text { t-value }}{2.79}$} & \multirow{2}{*}{$\frac{\mathrm{p} \text {-value }}{0.005}$} & \multicolumn{2}{|c|}{$95 \%$ Confidence Interval } & \multirow{2}{*}{$\begin{array}{l}\text { Sig } \\
* * *\end{array}$} \\
\hline Energy & & & & & 0.276 & 1.580 & \\
\hline Transport & 2.050 & 0.967 & 2.12 & 0.034 & 0.155 & 3.946 & $* *$ \\
\hline Pollution & 4.140 & 2.406 & 1.72 & 0.085 & -0.576 & 8.856 & $*$ \\
\hline CPI & 0.494 & 0.092 & 5.39 & 0.000 & 0.314 & 0.674 & $* * *$ \\
\hline Trade & -0.077 & 0.149 & -0.52 & 0.603 & -0.369 & 0.214 & \\
\hline GDPpc & 0.000 & 0.000 & 1.29 & 0.196 & 0.000 & 0.000 & \\
\hline GFCF & -0.390 & 0.178 & -2.19 & 0.028 & -0.739 & -0.041 & $* *$ \\
\hline IVA & 0.465 & 0.149 & 3.12 & 0.002 & 0.172 & 0.758 & *** \\
\hline Unemp & 0.024 & 0.129 & 0.19 & 0.853 & -0.229 & 0.277 & \\
\hline Constant & -67.224 & 13.061 & -5.15 & 0.000 & -92.823 & -41.625 & $* * *$ \\
\hline \multicolumn{2}{|l|}{ Mean dependent var } & 1.712 & \multirow{2}{*}{\multicolumn{2}{|c|}{ SD dependent var }} & & 4.150 & \\
\hline \multicolumn{2}{|l|}{ Overall r-squared } & 0.442 & & & & 90.000 & \\
\hline \multicolumn{2}{|l|}{ Chi-square } & 63.486 & \multicolumn{2}{|c|}{ Prob > chi2 } & & 0.000 & \\
\hline \multicolumn{2}{|l|}{ R-squared within } & 0.439 & \multicolumn{2}{|c|}{ R-squared between } & & 0.689 & \\
\hline
\end{tabular}


Source: Authors' calculations. Sig - significance level: * indicates significance at 0.10 level, ** indicates significance at 0.05 level, *** indicates significance at 0.01 level

Considering regression analysis results for this particular country cluster, we might conclude that all environmental fiscal instruments positively influence its economic development. Namely, an increase of energy taxes share in total revenues from taxes and social contributions in $1 \%$ results in GDP growth rate of $0.928 \%$ at $1 \%$ level; an increase of the ratio of transport taxes total revenues from taxes and social contributions in $1 \%$ results in an increase of independent variable in $2.05 \%$ at $5 \%$ level; an increase of taxes on pollution/resources results in boosting of economic dynamics in $4.14 \%$ at $10 \%$ level. Thus, we can conclude that environmental taxes might become an integral economic policy element in less developed post-socialistic European countries.

Regression analysis results for the fourth cluster of countries are presented in Table 6.

Table 6

Regression results for cluster 4

\begin{tabular}{|c|c|c|c|c|c|c|c|}
\hline & \multirow{2}{*}{$\begin{array}{c}\text { Coefficient } \\
-0.005\end{array}$} & \multirow{2}{*}{$\begin{array}{c}\text { Standard } \\
\text { Error } \\
0.329\end{array}$} & \multirow{2}{*}{$\begin{array}{c}\mathrm{t} \text {-value } \\
-0.01\end{array}$} & \multirow{2}{*}{$\frac{\mathrm{p} \text {-value }}{0.988}$} & \multicolumn{2}{|c|}{$95 \%$ Confidence Interval } & \multirow[t]{2}{*}{ Sig } \\
\hline Energy & & & & & -0.649 & 0.639 & \\
\hline Transport & 0.300 & 0.901 & 0.33 & 0.739 & -1.466 & 2.065 & \\
\hline Pollution & -1.192 & 2.933 & -0.41 & 0.684 & -6.942 & 4.557 & \\
\hline CPI & 0.122 & 0.139 & 0.88 & 0.380 & -0.151 & 0.394 & \\
\hline Trade & 0.368 & 0.118 & 3.13 & 0.002 & 0.138 & 0.599 & *** \\
\hline GDPpc & 0.000 & 0.000 & -0.02 & 0.983 & 0.000 & 0.000 & \\
\hline GFCF & 0.155 & 0.182 & 0.85 & 0.396 & -0.203 & 0.512 & \\
\hline IVA & -0.131 & 0.123 & -1.07 & 0.285 & -0.371 & 0.109 & \\
\hline Unemp & -0.071 & 0.100 & -0.71 & 0.477 & -0.267 & 0.125 & \\
\hline Constant & -12.425 & 18.738 & -0.66 & 0.507 & -49.151 & 24.302 & \\
\hline \multicolumn{2}{|l|}{ Mean dependent var } & 0.719 & \multicolumn{2}{|c|}{ SD dependent var } & \multicolumn{2}{|r|}{3.717} & \\
\hline \multicolumn{2}{|l|}{ Overall r-squared } & 0.451 & \multicolumn{2}{|c|}{ Number of obs } & \multicolumn{2}{|r|}{80.000} & \\
\hline \multicolumn{2}{|l|}{ Chi-square } & 57.573 & \multicolumn{2}{|c|}{ Prob $>$ chi2 } & \multicolumn{2}{|r|}{0.000} & \\
\hline \multicolumn{2}{|l|}{ R-squared within } & 0.264 & \multicolumn{2}{|c|}{ R-squared between } & \multicolumn{2}{|r|}{0.944} & \\
\hline
\end{tabular}

Source: Authors' calculations. Sig - significance level: * indicates significance at 0.10 level, ** indicates significance at 0.05 level, *** indicates significance at 0.01 level

Thus, it should be noted that cluster 4 consists of European countries that have somewhat vulnerable trends of socioeconomic development. Considering regression analysis results for this group of countries, we might underline that it was not empirically proved the hypothesis about the positive influence of environmental taxes on country economic growth. All independent variable coefficients are insignificant at $1 \%, 5 \%$, or $10 \%$ levels. Therefore, for these countries, environmental fiscal instruments could not be considered a priority in boosting economic development.

\section{CONCLUSION}

In this paper, we aimed to explore how environmental tax system architecture in different countries depends on socioeconomic preconditions. We hypothesized that an increase in revenues from energy, transport, and pollution/resource taxes would positively influence a country's economic growth. We have used a data set of environmental tax revenues (as a share of total tax revenues and contributions) and proxies of social and economic country development collected for 30 European countries. Based on Ward's hierarchy cluster analysis, it was identified four country clusters that have common socioeconomic trends. 
In turn, on the next stage, panel data regression analysis for each certain country cluster allows identifying peculiarities of environmental taxes impact on GDP growth rate and creating a background for the recommendations of prioritization of fiscal environmental instruments in certain socioeconomic conditions. Specifically, for the first cluster, which consists of highly developed European countries, it is recommended to pay less attention to transport environmental taxes because they inhibit economic dynamics. In contrast, the other two groups of environmental taxes are neutral to ensure economic growth for this country sample. The second cluster consists of Ireland, Norway, and Switzerland. Opposite to the previous group, it is recommended to build these countries' environmental tax system on transport and energy taxes and pay less importance to taxes on pollution that negatively impact the country's economic growth. The third cluster, which covers moderately developed post-socialistic European countries, illustrates the highest relationships of environmental taxes and macroeconomic dynamics. Specifically, this cohesion is positive, and the logical link of fiscal instruments from less to more significant is as follows "taxes on pollution/resources $\rightarrow$ transport taxes $\rightarrow$ energy taxes." Finally, the fourth cluster is the most diversified. It covers countries with vulnerable socioeconomic dynamics, for which it was not empirically proved statistically significant relations between environmental taxes and GDP growth. Consequently, for these countries environmental fiscal instruments could not be considered a priority in boosting economic development. Thus, as a conclusion, we might note that the environmental tax system's architecture highly depends on socioeconomic preconditions, which might be considered both in terms of fiscal policy and economic policy development.

\section{ACKNOWLEDGEMENT}

This paper was supported by the Ministry of Education and Science of Ukraine and National Research Foundation of Ukraine and performed the results of the projects "Structural-functional multiplex model of ecological tax system building in Ukraine in the context of national security" (registration number 0119U100759) and "Stochastic modelling of road map for harmonizing national and European standards for energy market regulation in the transition to a circular and carbon-free economy" (0120U104807) respectively.

\section{REFERENCES}

Alimuddin, A., Hasnidar, H., Bura, M. T., \& Anggraeni, F. L. (2020). The Effect of Applying Balanced Scorecards Environmental Performance. Polish Journal of Management Studies, 21(1), 22-33. doi: 10.17512/pjms.2020.21.1.02

Atkociuniene, Z. O. \& Mikalauskiene, A. (2019). Knowledge Management Influence on Implementing Sustainable Development Means in the Organization. Transformations in Business \& Economics, 18(3), 546-564.

Atta Mills, E. F. E., Zeng, K., \& Baafi, M. A. (2020). The economy-energy-environment Nexus in IMF's Top 2 biggest economies: a TY approach. Journal of Business Economics and Management, 21(1), 1-22. https://doi.org/10.3846/jbem.2019.11321

Bhowmik, D. (2019). Decoupling CO2 Emissions in Nordic countries: Panel Data Analysis. SocioEconomic Challenges, 3(2), 15-30. http://doi.org/10.21272/sec.3(2).15-30.2019.

Bilan, Y., Lyeonov, S., Stoyanets, N., \& Vysochyna, A. (2018). The impact of environmental determinants of sustainable agriculture on country food security. International Journal of Environmental Technology and Management, 21(5/6), 289-305. doi: 10.1504/IJETM.2018.100580

Bilan, Y., Samusevych, Y., Cichocka, I., Vysochyna, A., \& Woźniak, A. (2020). Do Eco-Innovations Boost Entrepreneurship Development? Proceedings of the 35th International Business Information Management Association Conference, 1-2 April 2020, Seville, Spain. Retrieved from: https://ibima.org/accepted-paper/do-eco-innovations-boostentrepreneurship-development

Bilan, Y., Vasilyeva, T., Lyeonov, S., \& Bagmet, K. (2019). Institutional complementarity for social and economic development. Business: Theory and Practice, 20, 103-115. https://doi.org/10.3846/btp.2019.10. 
Boiko, A,. \& Samusevych, I. (2017). The role of tax competition between the countries of the world and the features of determining the main tax competitors of Ukraine among the European countries. Financial Markets, Institutions and Risks, 1(1), 72-79. doi: 10.21272/fmir.1(1).72-79.2017

Cebula, J., Chygryn, O., Chayen, S. V., \& Pimonenko, T. (2018). Biogas as an alternative energy source in Ukraine and Israel: Current issues and benefits. International Journal of Environmental Technology and Management, 21(5-6), 421438. doi:10.1504/IJETM.2018.100592

Chovancová, J., \& Tej, J. (2020). Decoupling economic growth from greenhouse gas emissions: the case of the energy sector in V4 countries. Equilibrium. Quarterly Journal of Economics and Economic Policy, 15(2), 235-251. https://doi.org/10.24136/eq.2020.011

Chygryn, O., Pimonenko, T., Luylyov, O., \& Goncharova, A. (2018). Green bonds like the incentive instrument for cleaner production at the government and corporate levels: Experience from EU to Ukraine. Journal of Environmental Management and Tourism, 9(7), 1443-1456. doi:10.14505/jemt.v9.7(31).09

Dkhili, H. (2018). Environmental performance and institutions quality: evidence from developed and developing countries. Marketing and Management of Innovations, 3, 333-244. http:/ / doi.org/10.21272/mmi.2018.3-30

Eddassi, H. (2020). Fiscal Regime and Tax Policy in Resource-Rich Countries In The Process Of Globalization: Literature Review. SocioEconomic Challenges, 4(2), 67-77. https://doi.org/10.21272/sec.4(2).67-77.2020.

Grybaite, V., \& Stankevičienè, J. (2018). An empirical analysis of factors affecting sharing economy growth. Oeconomia Copernicana, 9(4), 635-654. https://doi.org/10.24136/oc.2018.031

He, S. (2019). The Impact of Trade on Environmental Quality: A Business Ethics Perspective and Evidence from China. Business Ethics and Leadership, 3(4), 43-48. http://doi.org/10.21272/bel.3(4).43-48.2019.

Holotová, M., Nagyová, L., \& Holota, T. (2020). The impact of environmental responsibility on changing consumer behaviour - sustainable market in Slovakia. Economics and Sociology, 13(3), 84-96. doi:10.14254/2071789X.2020/13-3/6

Hrytsenko, L.L. (2014). Rationale for priority sources of investment support of the national economy of Ukraine. Actual Problems of Economics, 159(9), 84-91.

Jonek-Kowalska, I. (2019). Transformation of energy balances with dominant coal consumption in European economies and Turkey in the years 1990-2017. Oeconomia Copernicana, 10(4), 627-647. https://doi.org/10.24136/oc.2019.030

Kasych, A., \& Vochozka, M. (2017). Theoretical and methodical principles of managing enterprise sustainable development. Marketing and Management of Innovations, 2, 298-305. http://doi.org/10.21272/mmi.2017.2-28

Kharlamova, G., Nate, S., \& Chernyak, O. (2016) Renewable energy and security for Ukraine: challenge or smart way? Journal of International Studies, 9(1), 88-115. DOI: 10.14254/2071-8330.2016/9-1/7.

Koziuk, V., Hayda, Y., Dluhopolskyi, O., \& Klapkiv, Y. (2019). Stringency of environmental regulations vs. global competitiveness: Empirical analysis. Economics and Sociology, 12(4), 278-298. doi:10.14254/2071-789X.2019/12$4 / 17$

Kubaienko, A. (2018). Activation of the Economic Security of Ukraine in Terms of the European Integration. Montenegrin Journal of Economics, 14 (2), 91-114. DOI: 10.14254/1800-5845/2018.14-2.6.

Lyulyov, O., Chortok, Y., Pimonenko, T., \& Borovik, O. (2015). Ecological and economic evaluation of transport system functioning according to the territory sustainable development. International Journal of Ecology and Development, 30(3), 1-10. Retrieved from https://www.scopus.com/record/display.uri?eid=2-s2.084940377261 \&origin $=$ resultslist

Mačaitytė, I., \& Virbašiūtè, G. (2018). Volkswagen Emission Scandal and Corporate Social Responsibility - A Case Study. Business Ethics and Leadership, 2(1), 6-13. Doi: 10.21272/bel.2(1).6-13.2018

Makarenko, I. O., Smolennikov, D. O., \& Makarenko, S. M. (2019). Ukrainian national strategy for corporate social and environmental responsibility as a framework of responsible business conduct. Espacios, 40(22). Retrieved from https://www.scopus.com/record/display.uri?eid=2-s2.0-85068250511\&origin=resultslist

Matvieieva, Y., Myroshnychenko, I., \& Valenkevych, L. (2019). Optimization model of the socio-ecological-economic development of the administrative territory. Journal of Environmental Management and Tourism, 10(8), 1874-1899. doi:10.14505/jemt.v10.8(40).17 
Mentel, G., Vasilyeva, T., Samusevych, Y., \& Pryymenko, S. (2018). Regional differentiation of electricity prices: Socialequitable approach. International Journal of Environmental Technology and Management, 21(5-6), 354-372. DOI: 10.1504/IJETM.2018.100583

Mikhaylova, A., Mikhaylov, A., Savchina, O., \& Plotnikova, A. (2019). Innovation landscape of the Baltic region. Administratie si Management Public, (33), 165-180. DOI: 10.24818/amp/2019.33-10.

Myroshnychenko, I., Makarenko, I., Smolennikov, D., \& Buriak, A. (2019). The approach to managing corporate social and environmental responsibility in manufacturing. TEM Journal, 8(3), 740-748. doi:10.18421/TEM83-07.

Ngoc Huy, D. (2018). Tax rates effects on the risk level of listed Viet Nam real estate firms during global economic crisis 2007-2009. Economics, Management and Sustainability, 3(2), 29-41. doi:10.14254/jems.2018.3-2.3.

Pavlyk, V. (2020). Assessment of green investment impact on the energy efficiency gap of the national economy. Financial Markets, Institutions and Risks, 4(1), 117-123. http://doi.org/10.21272/fmir.4(1).117-123.2020.

Petrushenko, Y., Vadym, A., Vorontsova, A., \& Ponomarenko, O. (2020). Sustainable development goals as a tool for strategic planning in communities: A bibliometric analysis of research. Paper presented at the E3S Web of Conferences, $\quad 202 \quad$ doi:10.1051/e3sconf/202020203005 Retrieved from https://www.scopus.com/record/display.uri?eid=2-s2.0-85096415016\&origin=resultslist

Piłatowska, M. \& Włodarczyk, A. (2018). Decoupling Economic Growth From Carbon Dioxide Emissions in the EU Countries. Montenegrin Journal of Economics, 14 (1), 7-26. DOI: 10.14254/1800-5845/2018.14-1.1.

Pimonenko, T., Bilan, Y., Horák, J., Starchenko, L., \& Gajda, W. (2020). Green brand of companies and greenwashing under sustainable development goals. Sustainability (Switzerland), 12(4). doi:10.3390/su12041679

Raszkowski, A., \& Bartniczak, B. (2018). Towards Sustainable Regional Development: Economy, Society, Environment, Good Governance Based on the Example of Polish Regions. Transformations in Business \& Economics, 17(2), 225-245.

Rui, L., Sineviciene, L., Melnyk, L., Kubatko, O., Karintseva, O., \& Lyulyov, O. (2019). Economic and environmental convergence of transformation economy: The case of china. Problems and Perspectives in Management, 17(3), 233241. doi:10.21511/ppm.17(3).2019.19

Sibanda, M., \& Ndlela, H. (2020). The link between carbon emissions, agricultural output and industrial output: evidence from South Africa. Journal of Business Economics and Management, 21(2), 301-316. https://doi.org/10.3846/jbem.2020.11408

Ślusarczyk, B. (2018). Tax incentives as a main factor to attract foreign direct investments in Poland. Administratie si Management Public, (30), 67-81. doi: 10.24818/amp/2018.30-05.

Sokolovska, A., Zatonatska, T., Stavytskyy, A., Lyulyov, O., \& Giedraitis, V. (2020). The impact of globalization and international tax competition on tax policies. Research in World Economy, 11(4), 1-15. doi:10.5430/rwe.v11n4p1

Stankevičiene, J., \& Nikanorova, M. (2020). Eco-innovation as a pillar for sustainable development of circular economy. Business: Theory and Practice, 21(2), 531-544. https://doi.org/10.3846/btp.2020.12963

Stavytskyy, A., Kharlamova, G., Giedraitis, V., \& Šumskis, V. (2018). Estimating the interrelation between energy security and macroeconomic factors in European countries. Journal of International Studies, 11(3), 217-238. doi:10.14254/2071-8330.2018/11-3/18.

Vafaei, S.A., Azmoon, I., \& Fekete-Farkas, M. (2019). The Impact of Perceived Sustainable Marketing Policies on Green Customer Satisfaction. Polish Journal of Management Studies, 19(1), 475-491. doi:10.17512/pjms.2019.19.1.36.

Vasilyeva, T., Bilan, S., Bagmet, K., \& Seliga, R. (2020). Institutional development gap in the social sector: Crosscountry analysis. Economics and Sociology, 13(1), 271-294. doi:10.14254/2071-789X.2020/13-1/17.

Vasylyeva, T. A., \& Pryymenko, S. A. (2014). Environmental economic assessment of energy resources in the context of ukraine's energy security. Actual Problems of Economics, 160(1), 252-260.

Vysochyna, A. V., Samusevych, I. V. \& Tykhenko, V. S. (2015). The effect of tax tools in environmental management on region's financial potential. Actual Problems of Economics, 171 (9), 263-269. Retrieved from https://www.scopus.com/record/display.uri?eid=2-s2.0-84950119053\&origin=resultslist.

Vysochyna, A., Stoyanets, N., Mentel, G. \& Olejarz, T. (2020). Environmental Determinants of a Country's Food Security in Short-Term and Long-Term Perspectives. Sustainability (Switzerland), 12(10). doi:10.3390/su12104090. 